\title{
Pricing Strategies for Companies During the COVID-19 Pandemic
}

\author{
Lovely Chopra, Netaji Subhas University of Technology, New Delhi, India \\ Rohan Shareshtha Verma, Netaji Subhas University of Technology, New Delhi, India \\ Pratap Chandra Mandal, Indian Institute of Management, Shillong, India
}

\begin{abstract}
Companies adopt pricing strategies to maximize their profits. However, in light of an ongoing pandemic, these strategies have been put under the scanner across industries. Companies need to modify their pricing strategies to adapt to these unprecedented times. The study focuses on these pricing strategies, their necessity during the pandemic, and how they can be effectively implemented without any long-term implications for various companies and businesses. The study focuses on various aspects of pricing and the suitability of pricing strategies during the pandemic. The study suggests pricing strategies which companies may follow. Pricing strategies of several industries which are in crisis are also discussed. The study will help companies to understand the economic situation and formulate pricing strategies accordingly. Such pricing strategies will allow companies to satisfy their customers, sustain in the competition, and achieve business excellence.
\end{abstract}

\section{KEYWORDS}

Dynamic Pricing, Fair Pricing, Price Optimization, Price Slashing, Pricing Power

\section{INTRODUCTION}

Pricing is a technique to decide upon the value that a company attaches to its product or service. The objective of every firm is to maximize profits (Cushing-Daniels, 2020). Pricing is the instrument through which companies achieve the goal of profit maximization. Pricing is the single most important aspect that decides the future of the product in the market (Gao, 2020). Consequently, companies require evaluating their pricing strategies regularly to align with the market and customer capabilities. The evaluation is more essential during crisis situations (Y1lmaz, Ünal, \& Dursun, 2019). During crisis situations like the present pandemic, most companies require reforming their applications and engagements with customers. However, many of the companies are unaware about the latest customer dynamics that have been shaped up by the pandemic (Lessard, 2019). Because of these reasons, despite having the willingness to reform, many small companies are not able to cater to their target audience.

Previous researches have emphasised on pricing techniques during normalcy and even during a crisis (Kim, Roehl, \& Lee, 2019; Blinder, Ehrmann, De Haan, \& Jansen, 2017). Given the unprecedented nature of COVID-19 and the turbulence created, there are unforeseen circumstances where normal rules do not seem to apply (Rascão, 2019). Consequently, it is imperative to conduct research on what pricing strategies companies should adopt during a pandemic. Coronavirus is shaking up consumer behaviour on a mass scale. While most of the economy's wounds have been laid bare of late because of the pandemic, some have been affected less as compared to others in an

\section{DOI: $10.4018 /$ IJBSA.287111}

This article published as an Open Access article distributed under the terms of the Creative Commons Attribution License (http://creativecommons.org/licenses/by/4.0/) which permits unrestricted use, distribution, and production in any medium, provided the author of the original work and original publication source are properly credited. 
era where businesses are closing, jobs are decreasing, and the economy is shrinking. There has been an unprecedented uncertainty in the market from the supply chain to the demands of the products (Bryce, Ring, Ashby, \& Wardman, 2020). Multinational companies having a major demand for their products in the western markets, have their production centres in South Asia. This is one of the multiple examples of how globalisation has converged business in different countries. With the increased trade restrictions, most businesses have to take tough decisions. The consumers are not prioritizing luxury items for the time being in light of the increased tensions and recession that might succeed this pandemic. The COVID-19 pandemic is both a supply and demand shock. The pandemic has resulted in economic crisis because consumers have become cautious and thrifty.

The pandemic arising during to COVID-19 is a recent phenomenon. Companies are unsure about the pricing strategies they should adopt during this crisis. Few research studies have aimed at addressing the issue. The study aims at addressing this research gap.

The objective of the study is to understand the pricing techniques that would be taken up by companies during the pandemic and in a post-COVID world. The study also tries to address the feasibility issues related to the application of each of those strategies.

The methodology adopted is the conceptual and the qualitative analysis of the literature related to COVID-19 and the strategies companies are adopting to handle the crisis. Primary data was not collected, and empirical analysis was not done.

The contributions and the novelty of the study lie in the fact that the modern pricing techniques are analyzed and the applicability of such techniques during the pandemic is highlighted. As consumers start to bifurcate items into "essential" and "non-essential", the market for most non-essential services is at a standstill and faces a prospect of bleak short-term future at the very least. At this point in time, most of the firms are looking to revamp their pricing techniques to cope with the wrath they are facing due to the pandemic. The businesses are being forced to do analysis about how the pandemic is going to impact their industry and then follow it up with how individually it is going to impact the business itself. The business strategies and their operational and financial aspects are addressed in the study. As businesses adopt all those measures, each factor would individually impact the pricing strategies of the companies. These are discussed in the study. Given that the COVID-19 pandemic is a recent phenomenon and many of the aspects about the pandemic are not well known, the study should be considered as an introductory study aimed to promote more research about the focus theme. It is also difficult to predict the future and to suggest long term strategic plans of companies and businesses. However, within the boundaries of limited knowledge, the study aims to provide suggestions for businesses after a careful analysis of the present situation.

The study is structured as follows:

Section 2 discusses about the importance of pricing strategies for companies. Section 3 focuses on the economic restrictions created by the pandemic. The importance of aligning company goals with pricing strategies is highlighted in section 4 . Section 5 discusses about retention of pricing power. The factors influencing pricing strategies during the pandemic are discussed in section 6. Sections 7 and 8 discuss about price optimization and changes in market demography and customer loyalty caused by the pandemic. Pricing during the pandemic is discussed in section 9 with sub-sections 9.1 and 9.2 focusing on e-commerce and the relationship between inflation and the pandemic respectively. Section 10 discusses about the pricing strategies which companies should adopt to reduce the impact created by the pandemic. Sub-sections 10.1, 10.2, and 10.3 discuss about dynamic pricing, fair pricing, and price slashing respectively. Section 11 focuses on the crisis developed in various industries due to the pandemic. The four industries highlighted include oil industry (sub-section 11.1), real estates and properties (sub-section 11.2), aviation industry (sub-section 11.3), and pharmaceuticals industry (sub-section 11.4). Section 12 discusses about the strategies which companies and businesses may adopt to restore normal business situations. Section 13 discusses the salient points of the study with sub-sections 13.1 and 13.2 highlighting the theoretical implications and the managerial implications of 
the study. Section 14 concludes the study with sub-sections 14.1 and 14.2 highlighting the limitations of the study and the avenues of future research respectively.

\section{IMPORTANCE OF PRICING}

Pricing is often regarded as the single most important entity in business because it is the only avenue that generates revenue for the company (Nair, 2019). Price is a major aspect that drives the potential customers to make the sales or drive them away to competitors that offer more value for money in their opinion (Jommi, Armeni, Costa, Bertolani, \& Otto, 2020). Pricing also reflects to consumers the value that companies attach to their services (Raja, Frandsen, Kowalkowski, \& Jarmatz, 2020). The benefits of optimum pricing can save companies substantial amount of money and can significantly boost the revenues up. Although pricing is important, companies are often guilty of undervaluing the overwhelming influence of pricing in attracting customers (Krutova, Nesterenko, \& Levina, 2019). The economic slowdown because of the 2008-09 recession and slow recovery have shaped up modern day pricing techniques. The present pandemic may also decide the pricing techniques which companies need to adopt. Consequently, the pricing strategies adopted by governments have major implications.

\section{ECONOMIC RESTRICTIONS}

The pandemic has resulted in tension among people because a large section of the population is more vulnerable than ever (Scott, 2020). Getting fired from jobs to pay cuts have become a norm and this would significantly impact the spending powers of the consumers. It is critical to adopt suitable pricing strategies to maintain good relationships with customers and yet generate desirable profits (Schoonveld, 2020). Companies will lose customers if they charge exorbitant prices during these tough times. Also, people might not accept that brand when the economy is back to normal (Baker, Baugh, \& Sammon, 2020). However, if the brand decides to put itself out there as a brand for people, and a brand that cares, it definitely will have an added advantage when things start to get better. Promotions and increments should be sacrificed by companies (Vassiliadis, Skoulas, \& Gkarane, 2020). A study conducted by PwC in the USA suggests that there is a significant change in how consumers buy the products with the process of digitalisation. The process is influenced by the global pandemic amidst the security concerns that come with venturing to stores for groceries (Spychalska-Wojtkiewicz, 2020). Comparison of prices for items like groceries has become feasible and that makes prices competitive. Companies and brands offering competitive prices will delight customers. Such companies and brands will secure a greater market share.

\section{ALIGNMENT OF PRICING STRATEGIES WITH COMPANY GOALS}

In the present situation of crisis, it is crucial that companies and businesses assess their business models and transfer pricing approaches and plan their long-term and short-term responses accordingly (Sigala, 2020). It is important that revisions to transfer pricing approaches are seen more from the perspective of aligning overall strategic responses of the business towards a changed scenario. As the pandemic has slowly unfolded, companies are forced to take a hard look at their policies and assess the business models and pricing practices (Valente, Valente, \& Vincenti, 2020). It is important for companies to ensure that any revision in pricing strategy that happens during these times should align with the overall strategic responses of the companies. Strategies should be formed keeping in mind the short-term and long-term consequences of those policies (Amankwah-Amoah, 2020). When the virus and its after-effects on the economy will finally vanquish, companies might have to face the wrath of consumers if their strategies are only based on short-term reforms. People have different perceptions of brands that make them unique to their audience. It is important for companies to preserve 
the uniqueness and identity during these tough times. People should be able to associate themselves with the brand. This will increase the propensity of retention of customers from pre-COVID era ( $\mathrm{Li}$, Hallsworth, \& Coca-Stefaniak, 2020). A significant change in pricing for worse would impact the capacity of the company in this domain. Companies should not charge customers more than they associate the cost of the product with. Customers should perceive to receive value from the products.

\section{RETENTION OF PRICING POWER}

Retention of pricing power becomes a necessity in an unstable market (Liu \& Wang, 2020). Pricing power usually represents the stronghold established by a company in an industry and in scenarios when there is no competition (Naumzik \& Feuerriegel, 2020). It is difficult for companies to establish the stronghold. Many of the companies set prices for their products in line with the industry norms. In times of uncertainty, retention of pricing power has become onerous because of fundamental change in supply, demand, and customer behaviour. Warren Buffet described it aptly (Liozu, 2019):

"The single most important decision in evaluating a business is pricing power. If you've got the power to raise prices without losing business to a competitor, you've got a very good business. And if you have to have a prayer session before raising the price by 10\%, then you've got a terrible business".

Pricing power refers to the price that a company gets in exchange for the value it delivers to the customers, keeping them aligned with principles of the company whilst implementing sustainable pricing strategies. Pricing power becomes a necessity when a company knows a price way is around the corner or the cost of capital is not recovered from the company (Yan, Liu, Xu, \& He, 2020).

\section{FACTORS INFLUENCING PRICING STRATEGIES}

There are several factors which influence and determine the pricing strategies formulated by companies. The two most important factors include - market conditions and competitors.

Market Conditions: Markets are going through a peculiar time with both supply and demand uncertainty. Markets that are rich in opportunity would see a greater influx of people trying to enter the market and therefore, odds of establishing pricing powers in products like healthcare and sanitisation would be rather improbable. Other markets which are already dipping would find it tough to even retain the price of the products. These times can be characterized by lower pricing powers. However, companies should consider multiple factors that need to be considered (Dong, Rao, Liu, Jiang, Lu, \& Guo, 2019).

Competitors: Competitors that have experienced both increased demand and lower demand set the tone for the market. In the markets with increased demand and where the government avoids price gouging, price works out well for consumers because of the increased competition as many industries are shifting from their traditional base to work in the sectors with increased demand (Taleizadeh $\&$ Sadeghi, 2019). Also, many industries and businesses which are forced to shut down will give a greater power to companies who have managed to weather the storm and greater pricing power may be achieved as businesses start to unlock because of the lower competition (Chen, Zhao, Yan, \& $\mathrm{Li}, 2020$ ). Another aspect of the volatile market is the propensity of success for companies that are willing to focus on customer value with emphasis on innovation (Nik Hashim, Hock Ann, Ansary, \& Xavier, 2020). Companies discover new trends about spread of the pandemic, efforts to control it, and how other countries are fighting it. However, because of the large amount of information that companies need to process every day, it becomes difficult for them to analyze the information (Pich $\&$ Sardjono, 2020). 
Pricing power is often a result of hard work of a team to analyse the trends in market which creates a roadmap for success (Adler, 2020). Companies start with a clear roadmap and then enforce the pricing framework. Companies take tough decisions. Companies try to optimise the price to be charged and the profits. However, since the situation is an exception, the analysis may not be fully effective. Nevertheless, companies can still generate value that can be derived from past behaviour of consumers and strong leadership during these tough times (d'Aguiar, da Silva, da Silva, Marques, $\&$ de Gaspi, 2020). Pricing power, if used correctly, would deliver a huge competitive advantage for companies.

\section{PRICE OPTIMISATION}

Price optimisation is a process that aims to maximize the profits through prices after understanding the elasticity of their customers and the industry itself. Optimal pricing is especially important for companies that wish to link their business volumes with profits (Uncles, Dowling, \& Hammond, 2003) As the competitiveness of the industries increases, getting optimal prices right decides the profits generated, especially in these times. Many companies are trying to adapt to these times by launching new products for customer segments along the spectrum (Zhang, 2020). Components of effective price optimization model include (Lu, Zhang, \& Zhang, 2020):

- Cost models: These models predict the net claims and other costs for customers

- Competitive management analysis: This provides an analysis of the market in which the company operates.

- Customer elasticity models: These models reflect market competition and customer behaviour to predict volume of new business and renewal rates for customers at different rates.

- Optimization techniques: These integrate models to predict volume and price, identify the best prices, and the impact of price changes.

Price optimisation becomes a tougher challenge for companies during a pandemic with the demand and supply remaining standstill and with major industries at halt (Yang, 2020). The shift to digitalisation of the $\mathrm{B} 2 \mathrm{~B}$ market was apparent even before the pandemic and now considering the pandemic this process is expected to accelerate itself. According to a research by PROS by 2021, $40 \%$ of the people are expected to buy more than $50 \%$ of the products they use online and now with viruses at the forefront more and more people are shifting at a rate greater than expected (Tamraz \& Yang, 2017). Companies would have to make a shift towards dynamic pricing because of sudden shocks that will come in the market during these times.

\section{CHANGES IN MARKET DEMOGRAPHY AND LOYALTY}

A survey conducted by Price Waterhouse Coopers $(\mathrm{PwC})$ suggests that up to 50\% people are open to trying new products in this volatile market (Marth, Ploder, \& Dilger, 2020). This phenomenon of low customer loyalty stems from multiple issues that COVID-19 market has brought with it other than high mortalities and a broken healthcare system. During the time of crisis, individuals react with a certain degree of panic which causes instability in various places including the marketplace (Karabag, 2020). Supply chain disruption and hoarding have resulted in lack of availability of some of the products which promotes trial of new brands and thus lowering market loyalty. Price sensitivity has stood out as one of the more important factors for the consumers at the height of the weakened economy (Hammond \& Czaban, 2018). This shift in demographics could potentially be a route for smaller companies to occupy greater market share and disrupt the traditional strongholds in various industries (Sibbald, 2017). Those companies which adopt "customer-first policy" will succeed during 
the crisis. Customers are likely to engage with the companies which are more flexible and customer oriented. For example, a finance company in the city of Delhi in India decided to not only make all their workers work remote for the whole of 2020 after the outbreak started in Delhi during March but also granted them one month off to cope up with the stress of a pandemic. Customers at this time would prioritize pricing of the brands. They will also prefer those brands which provide them certain discounts and offers. This is one of the more impactful ways to capture the attention of customers during the pandemic (Teng, $\mathrm{Wu}, \&$ Chou, 2020).

\section{PRICING DURING COVID-19}

Companies find it difficult to formulate pricing strategies during COVID-19. There is insufficient knowledge of how customers would react, the unpredictability of the virus itself, and shift in B2B business techniques (Schoonveld, 2020). Businesses do not only have to worry about supply that is being disrupted or the demand side of things but also the fact that there would be unpredictable changes in consumer behaviour. Companies require adapting with all these issues. Other than the various factors that would affect pricing during these times, the section would also cover AI requirements and low touch pricing are shaping up the financial system of companies in the present context.

\subsection{E-Commerce}

E-commerce platforms will be the major interfaces for companies and those companies adopting and adapting to e-commerce will succeed (Bhatti, Akram, Basit, Khan, Raza, \& Naqvi, 2020). Retailers invest heavily in digital sales across recent years even though for majority of businesses online sales still represents a very tiny propagation of their revenues. Traditional channels are often prioritized while making discounts or even promotion decisions.

Companies require reaching out to their audience through e-commerce because consumers prefer online platforms for shopping (Mohamad, Hamzah, Ramli, \& Fathullah, 2020). Most companies have been slow at this transformation. Even those companies which have been quick to adapt are realistic with the prices they have delivered on the online platforms. This usually stems from the perceived lack of control for these companies over the power in negotiating tools as prices are out for everyone and companies sometimes adapt to the strategy of having less customers which are making them high profits as compared to relatively more customers with less profits (Purwanto, 2018).

There are three different ways in which companies can deliver prices to the market (Kusnadi \& Einarsson, 2020):

1. High Touch: When a business suggests a price and there are back and forth negotiations which ultimately decide the optimum price for the product and happens with in-person discussions. These types of deliveries are more traditionally followed. Those companies who entrust their negotiation power to get the optimum prices, prefer such pricing policies.

2. Medium Touch: Medium touch is basically a delivery of pricing in which there is lower flexibility as compared to high touch and is usually reserved for more expensive products in traditional terms.

3. Low Touch: Low touch delivery is when a company suggests the price and it is open to customers to compare with competitors with no scope of negotiations. Dynamic pricing comes under low touch pricing.

Low touch pricing is slowly becoming the most widely adopted technique with the onset of dynamic pricing (Lew, Cheer, Haywood, Brouder, \& Salazar, 2020). During this time when e-commerce is gaining popularity and online delivery is on a high, it automatically creates a market for low touch methods of delivering prices. Individuals also seem to trust AI and dynamic pricing 
more than they trust in person pricing techniques because they feel that this method is independent of their negotiating power with the business. They find this technique to be fairer and trustworthy. Negotiating with a salesperson for pricing can often be very subjective but the AI method is usually more objective.

\subsection{Inflation and COVID-19}

There are two major indicators of how well an economy is functioning - unemployment and inflation (Curdia, 2020). Inflation directly impacts the prices that are out in the market. For example, the USA government's number did show that there was $0.7 \%$ inflation in April 2020. That would ideally mean that the average prices which the citizens are paying for the products have gone down by $0.7 \%$. However, this is far from the actual scenario as the material itself that an average citizen is buying has been modified with the onset of this virus (Kapoor, 2020).

\section{PRICING STRATEGIES TO REDUCE THE IMPACT}

Companies adopt several pricing strategies to reduce the impact of the pandemic (Schoonveld, 2020). Companies charge different prices for various levels of services offered. For example, companies charge extra for fast delivery. Online product services, for example, have introduced a variety of annual plans or membership and other bundles that help in rendering numerous types of pricing tiers (Park, 2020). This strategy helps in cost-plus, value-based pricing as well as competitor-based pricing. Companies need to be vividly distinct in their services to overcome the sudden dampening in their demands, especially in the case of 'non-essential services' (Hao, Xiao, \& Chon, 2020). This strategy effectively helps the company in terms of implementing pricing tiers, various packages that incline with how the potential customers would like to make a deal. Besides this, it also helps build comprehensive learning of their targeted customer personas regularly and correspondingly affect their company's value metrics to their products. Many services implementing these have witnessed a quite manageable decrease in their consumer count and can look for prospects to getting their customer base revamped ( $\mathrm{Li}, 2020)$.

A "no show" customer is another primal problem faced by logistics in a company. In such a time of peak sale, customers should always pay the full fee even if they book in advance. This is a strategy many sectors such as airlines and other accommodation services have implemented in their logistics to avoid further loss of income as well as a commodity ( $\mathrm{Li}, 2020)$. Such accommodation services have already been witnessing a large-scale dip in their revenue, most evidently the largest bearer of loss in their sector due to negligible buyer's confidence spiked by the ongoing health crisis of COVID-19 (Sigala, 2020).

Price elasticity surges quickly during such crisis. The recession of 2007-2008 is a precedent for it. Pricing plays the most pivotal role in avoiding elasticity in the price-demand curve (Ma, 2020). An efficient method of pricing in such cases is an implementation of surcharges instead of base prices. These changes in surcharges are understandable to the customers and statistically, the price elasticity for surcharges is lower than base rates effectively. This strategy sets a range of prices that resonates with the current customer base of the company as well as providing significant margin for the growth and offset the company needs according to how they are surviving in the crisis and based on what services they render (Ma, 2020). Pricing audit and a descriptive analysis of the current pricing structure in terms of current metrics are also implemented exhaustively in such dire straits of supply-demand equations of companies (Mehboob, 2020).

The following parameters help a company to understand their customers' needs and the equation of their products and services attached to it (Helmold, 2020).

CAC: LTV ratio: Lifetime value (LTV) per customer and customer acquisition cost (CAC). This ratio indicates the value of a customer in their lifetime with respect to the cost of acquiring those customers. 
Average Revenue per User (ARPU): Total revenue spent divided in several subscribers. This metric helps in various sectors namely consumer communication, digital media, and network companies to understand better the needs of improving their services based on the responses of consumers and their demands.

Churn Rate: The annual percentage rate at which customer stop its subscription to a service or product.

These numbers play a pivotal role in how a company is performing in their respective sectors and reflect the consumers' persona on this service based on the churn rate. Accordingly, a company decides accurately the amount of investment a product or a service needs from their side and how much revenue can be potentially gained (Jabarzare \& Rasti-Barzoki, 2020).

\subsection{Dynamic Pricing}

Dynamic pricing model refers to the concept of setting products at different prices for various groups of people (Kandpal \& Patel, 2020). Companies should ensure that dynamic pricing does not result in price discrimination and lawsuits filed by customers or other bodies. With the economic crisis due to COVID-19 at the prime during this time, a dynamic model of pricing can help incur the offset for the lost revenue for companies (Hinterhuber, 2017).

Companies apply dynamic pricing tools which holistically analyses a combination of historical and real-time market data to generate appropriate price recommendations. The parameters used include past performance, local events, seasonality, and a company's data insights (Wang, Song, Yang, \& Huang, 2020). These augmented pricing tools can help a company grow its occupancy and revenue at an optimal pace within the boundaries of the regulations provided.

In crisis situations like the pandemic, the past may not be a true predictor for the future. So, companies should be cautious while generating customer insights from past data (Marolt, Zimmermann, \& Pucihar, 2020). "The trick is to knowing how to turn these data insights into actionable pricing strategies." - according to Ryan Saylor, Revenue manager at a pricing firm- Beyond Pricing. Besides this, another important strategy that companies have started to follow is to keenly monitor their market-level data to gauge how the company's business is striving within the stretching market demand. This even helps to set rates in the post-COVID recovery phase (Hao et al., 2020).

Business strategies should be experimented by companies to keep in check the demand and supply in their target. The companies should be able to adapt to the changing demand and supply of products through pricing strategies (Seaman, 2018). Companies use customer-based machine learning algorithm to categorise areas and locations predicting the factor of willingness to pay a comparatively higher price and thus showing a different price to a particular group of consumers (Gu, Kelly, \& Xiu, 2020). This form of pricing has seen a lot of precedented backlash and lawsuits which have been inclined towards consumers in a few cases.

Another form of pricing strategy effected by companies for online services is continuously monitoring and adjusting the prices of the products in a matter of minutes. Amazon.com monitors and updates prices every 10 minutes (Helmold, 2020). This strategy leads to the maximisation of revenues for its objectives and meets various levels of demands reaching within the company. Companies during COVID-19 crisis have already started aligning their pricing tools to cater the ranges of prices vis-a-vis customers' demands and understanding their persona and confidence on a regular basis with the ongoing pandemic (Balduzzi, Brancati, Brianti, \& Schiantarelli, 2020).

The pricing strategies provide companies with a better and greater control in the market's pricing strategy from contemporary companies. Companies have access to real-time trends of pricing to a much greater extent. This gives a clear picture of the trends of supply and demand of the products companies are dealing with and eventually leads to maximising the revenues by setting the right prices (Valkov, 2006). 


\subsection{Fair Pricing}

The previous section discussed about the various pricing strategies adopted by companies. However, companies should also ensure whether customers should pay an amount as high as set by the company for their services in the ongoing crisis. High prices may hamper the goodwill of the company, the buyer's confidence, and the company's brand image (Wang \& Huang, 2019). Ever since the outbreak of COVID-19 virus globally, governments of various countries have undertaken factors like price determination under its own control to ensure that the prices of essential services do not rise to unreasonable levels. This allows consumers to purchase the essential commodities at a monitored rate and this stabilizes the supply-demand equation. Setting lower prices for its products may have an adverse effect on the bottom line of companies (Nunes \& Machado, 2020). Again, a company may lose its customer base if it sets higher prices for its commodities and services. According to many business consultants, a business survives not only by its sales revenue but also by its goodwill and brand position (Adegboyega, 2020). Therefore, it is imperative for companies to set appropriate prices for products. It becomes even more important during the pandemic because customers are cash strapped (Schoonveld, 2020). Many companies tend to under-price their products and services to drive up volume. However, such strategies result in hampering the customer's image of value for money and the buyer's confidence in the process. Besides covering up its expenses as well as looking for a reasonable profit a business should look for, it should accurately resonate with what customers might be willing to pay for their commodities based on the economic situation of the market. Hence, fair pricing protects a company's goodwill and brand image and at the same time lets it strive through the economic times (Sibbald, 2017). Practices like regular survey and feedbacks from customers are prevalent in businesses in crucial times like this to analyse their pricing strategies and be in the balance of dynamic of the market holistically (Hartmann \& Lussier, 2020).

\subsection{Price Slashing}

Price slashing is a sales strategy used by companies during the economic crisis and market dips. It involves cutting prices to significantly lower rates with the motive of eliminating the market competition as well as generate revenue in a short period of time. This can be done through discounting, advanced purchases, or bulk buying (Smagulova, Doskeyeva, \& Radko, 2016). The discounted price given by the company is not perceived as a discount per se by the consumer. It seems like the true market value of the product. This definition seems standstill in a crisis like today's times. Henceforth, people have their willingness to buy the product only when there is a sale on that product. Otherwise, they tend to wait for the discount and not buy the products. This leads to a spiral of thinning margin for the company that leads to a potential revenue loss (Chen, Zha, Alwan, \& Zhang, 2020).

Homejoy is a cleaning service-based start-up in San Francisco, USA. The home cleaning represents an approximate $400 \$$ billion global market for an uber based overhaul. Homejoy being one of its kind in this field effected the strategy of algorithms for connecting homeowners with a scheduled visit and servicing with hired cleaners (Sravani, Tejaswini, \& Gowthami, 2016). The company earned $40 \$$ million initially. With the case of attraction of venture capitalists on this, enterprises such as PayPal and Google Ventures invested a huge deal of money in Homejoy (Cohan, 2017). Within two years, the company witnessed substantial growth. After this, the company declared that they had run out of money and the company did not produce any potential consumers or investors. Besides the litigation of the workers on the base of depriving them of extra hour wages and reimbursement, the biggest reason lied in the root of price slashing technique of Homejoy (Sravani et al., 2016). In a bid to grow the customer base and to eliminate competition in the cleaning-based services, Homejoy slashed their rates from $85 \$$ to an all-time low price of $19 \$$. This led to an immediate increase in customers in thousands of numbers in a few days. But surprisingly, this did not lead to the restoration of the slashed price of $85 \$$. This case of Homejoy indicates that many parameters should be analyzed before price slashing is implemented (Cohan, 2017). Also, price slashing may be potentially used as a precedent in COVID phase before implementing such a volatile strategy. 
Some other pricing strategies which are used in economic crisis include:

Loyal customer base: Entrepreneurs must vigorously build trust within their already targeted customer base. Press mentions, by-lined advertisements, and contents are some of the measures which companies may adopt to motivate customers to use the services of companies frequently (Ferguson, 2014). This helps a company decide an accurate range of prices that satisfies the customers and grow its revenue model.

Retargeting customers: Companies should try retargeting those customers that were once part of the company's service. Such customers are more likely to revert to the service through the strategy of retargeted advertisement (Barriga, 2019).

The interior designing company Lulu \& Georgia made retargeting the helm of their campaigning for a season to reclaim its once-existing customer base. The company witnessed monthly revenues doubling within a duration of four months. Besides that, it increased the LTV (lifetime value) of the customer by 29 percent in that season. Such incidents indicate that companies can target their customers in the times of crisis and enhance their customer bases.

During the recession of 2007-09, the producer prices dropped down by 8 percent and it took two years to completely revamp the revenue (Altunbas, Manganelli, \& Marques-Ibanez, 2017). In times of economic slump, companies need to maximise their assets even when the demand elasticity spirals down to keep their market shares and profit margins intact (Ranjan, 2016). Price slashing in such a slump hurts the profits in the long run and deprives companies of revenue when the economy is recovered. Companies employ price slashing strategically to defect customers from competitors and to attract a larger customer base. However, such actions may be counter-effective for companies because the revenues might be adversely affected (Brotspies \& Sellani, 2010).

\section{CRISIS IN INDUSTRIES DUE TO COVID-19}

The pandemic has created crisis in almost all industries. The degree of crisis varies from one industry to another. Some of the industries which have been affected most by the pandemic include oil industry, real estate and properties, aviation industry, and pharmaceuticals industry.

\subsection{Oil Industry}

Oil firms are facing real challenges as they try to curtail the amount of investment in the COVID-19 driven crisis exacerbated by the Russian-Saudi trade war (Alstadsæter, Bjørkheim, Kopczuk, \& Økland, 2020). The oil industry was all set to reach its production to half a trillion dollars this year as firms planned to expand their outputs. However, the outburst of COVID-19 effect has rendered most of the firm's work suspended. The forecasting of the industry has also taken a hiatus. The international energy agency released its statement regarding the first annual drop in oil demand since the recession of 2009 (Wossink, 2020). The pivotal international benchmark, Brent Crude has fallen from $60 \$$ per barrel to $25 \$$ per barrel in the month of the March 2020 itself. The US benchmark, WTI has witnessed a fall from $54 \$$ to $20 \$$. The sole cause is not just COVID-19 for this sector. The price of oil has been maintained by production limits concurred by the OPEC oil cartel of Saudi Arabia and a few other producers including Russia. However, Russia and Saudi failed to meet the agreement terms in March on taking a considerable cut to take into factor the falling demand due to the pandemic (Alstadsæter et al., 2020). Eventually, Saudi Arabia slashed its prices and following this, Russia took a steep drop in its prices. During these two challenges, most of the firms are figuring out how to curtail the prices more, shift their activities to the lowest cost fields they can, reduce investment, and focus on what dividends they can pay (Alstadsæter et al., 2020).

\subsection{Real Estates and Properties}

Property developers are not ready to sell their properties in the face of the COVID-19 induced economic crisis (Landier \& Thesmar, 2020). A few shares of these developers who need cash flow are ready 
for a discount of 5 to $12 \%$ only depending on the segment and region. Developers who can hold inventory will wait. Hence, the actual impact of COVID-19 crisis on estates will be felt only after a few months. It is also foreseeable that over-leveraged developers may bring out price cuts but not in terms of discounts rather in terms of offers and schemes (Kunzmann, 2020). Metropolitan cities have not faced any major challenges in the estate sector. Cities like Bengaluru of India have done well in recovering and sustaining the voracious appetite for estate dealers as transactions and proceedings have been easily possible in the post lockdown phase. On the other hand, cities like Noida of India have faced a whole different issue on the part of buyer confidence, as it largely lies on the construction work and ongoing activity at the site (Shah, 2020). So, buyers will book and buy the property after perhaps these two are met. The resale market also has a huge impact due to the crisis. Many shares of estate developers have panicked into slashing prices on poorly performing properties and for the need for cash flow. Markets are landlord-favoured, and it will take time to become favourable for tenants (Kunzmann, 2020).

\subsection{Aviation Industry}

One of the most enormous effects of the COVID-19 crisis has been on the aviation sector all over the world (Suau-Sanchez, P., Voltes-Dorta, A., \& Cugueró-Escofet, 2020). It directly impacts the passenger traffic, airport workforce proceedings, and incoming revenues. According to a report published by the International Civil Aviation Organization (ICAO), a total of 4.1 billion passengers used to travel by airlines every year worldwide for the year 2017 (Kerr, 2020). At present, four months into the COVID-19 crisis, the social and economic fallout of travel restrictions was possibly underestimated. Both domestic and international flights are restricted as much as possible to contain the virus in the region immediately. Many countries decided to allow their air network to revamp the economy while many countries decided to prioritise its community health over the economic crisis and grounded their airlines completely (Budd \& Ison, 2020). The crippling effect of restricted air operations is visible through the income to expenditure fraction. Many factors that are weighed in the sector are regular loans and lease liability airlines must pay based on how the planes were acquired. Even in pre-COVID phase, the airlines faced difficulty in paying lease rentals that were hardly offset by the income made by the air travel. At present, with lower incomes in the COVID-19 phase, it becomes extremely problematic for the companies to keep their airlines retained. As a result, a few airlines are shutting down while many others have decided to downsize or return their planes to the lessors (Akbar \& Kisilowski, 2020). Airlines have already faced huge losses in the last quarter of FY 201920 ever since precautionary measures were introduced few months back (Vinod, 2020). It is unlikely that this loss will be covered up anytime soon even with increased pricing on airfares. For now, the companies are implementing as much new innovative technologies in operations (Li-Ying \& Nell, 2020). However, the pace of economic recovery in this sector relies on passengers' confidence. Airlines companies are adopting many confidence-building measures to promote passengers' willingness to board flights (Iacus, Natale, Santamaria, Spyratos, \& Vespe, 2020).

\subsection{Pharmaceuticals Industry}

The pharmaceuticals sector in India is the third largest in the world. It manufactures $60 \%$ of the vaccines used worldwide. Many significant vaccines against diphtheria, pertussis, and tetanus required by World Health Organization (WHO) are catered by the Indian pharma industry (Chakraborty, 2020). Hence, the major portion of this industry's revenue comes from the export of these raw materials. India's active pharmaceuticals industry forecasted growth of $\$ 6$ billion in revenue by the end of 2020 (Chakraborty, 2020). It is clear that the Indian pharmaceuticals sector plays a pivotal role in global health scenario and is instrumental in saving millions of lives every year. This sector has been affected by the COVID induced crisis that has brought about various changes (Haleem, Javaid, \& Vaishya, 2020). The pandemic has disrupted the supply chain operations worldwide making them come to a standstill. Schedules of production have been shifted and the raw material prices have been hiked 
due to limited supply and shipping costs are sky high at this time. All these make the operations of the supply chain of the pharmaceutical firms extremely difficult to be carried out. Most of the raw materials are procured from China for pharmaceutical companies. Hence, the proceedings came to a standstill in the COVID-19 phase. Clinical trials and manufacturing as well have been restricted due to the obvious reasons and hence there are delays in product launching as well (By \& Jeetendra, 2020).

\section{RESTORING THE NORM}

Revival of the economy through carefully calibrated measures is of prime importance for all countries. Revival of sectors like agriculture, manufacturing, and services should be aimed at the earliest. At the same time, curtailing the use of geographic hotspots and vulnerable groups should be focused on. Another pivotal aspect is the revamping of supply chains and managing the supply chains effectively. Manufacturing and service enterprises may be allowed to operate while maintaining their hygiene practices. Restrictions in prices may be eased slowly and gradually. Companies will tend to pile up inventories. The increase would be in part because of companies' perception about uncertainty soon. The great recession of 2008 is a precedent from the history in which despite inventories remaining above average for many commodities, upward pressing in price did happen before the recession was over. Cash flow management needs to be an integral element of a company's overall COVID-19 risk assessment and action planning in the near term. Even for companies that have not yet been adversely affected, it is recommended that management teams of companies actively evaluate their cash flow requirements, develop appropriate actions under various scenarios, and assess potential risks in and to their customer base and supplier network (McAleer, 2020). Companies must be on alert to adapt to the market changes as and when they come. They must read and react immediately to make pricing and discount decisions. The plan would be highly dependent on key elements like ability to quickly interpret consumer signals and ability to extract useful insights. Every region in the world would have its own set of guidelines about the restrictions in lieu of the severity of the pandemic in that region. Retailers should be willing to adapt to them as soon as possible to stay ahead of the competitors and implement pricing decisions effectively. Lastly, retention of old customer base for successful businesses should be the priority and businesses should go to great lengths to ensure that trust factor between them and the consumers are not lost due to the halt. Effective implementation of all the above-mentioned measures would make the process of "restoring the norm" relatively easier.

\section{DISCUSSIONS}

The pandemic has exposed a lot of fault lines running in the trade and financial systems of companies and its architecture, rendering a disrupted governance system within the business along with manufacturing chains. The crisis has brought home some potent lessons for companies worldwide. The study has entailed all the precedents companies and business models have been pursuing keeping the operational view from modern commerce parlance in mind. The major policies under the purview of pricing that have been and can be used potentially under an ongoing economic crisis the businesses are going through, have been discussed descriptively.

\subsection{Theoretical Implications}

Academicians will understand and realize the nature of the pandemic and the effects created by COVID-19. The impact of COVID-19 on companies and businesses will be evident. Businesses will require substantial modifications and changes in pricing strategies and the initiatives taken so that the target markets adapt to the changes in pricing because of the pandemic. Academicians will be able to revisit the various aspects of pricing and suggest companies about which pricing strategies will be most effective during crisis situations. 


\subsection{Managerial Implications}

A company provides a variety of commodities and services. Pricing can be the most imperative factor in states of economic recession. Companies should formulate pricing strategies which align with their targets while maintaining values and ethics. Market research becomes a critical portion to be discussed before the companies decide on any pricing strategies. Therefore, the market demography, economic restrictions, retention of pricing power, and the competition for a company in its field will shape up the pricing strategies for businesses in the most certain ways. The pricing strategies depend on the model of the business including cost models and optimisation techniques as well, which help a company to monitor its supply chain management and meet its target customers' demands on a balanced level. Customer demands may be highly volatile due to the ongoing pandemic crisis. The potential pricing strategies are entailed in the study. Companies will precisely use techniques like price slashing and dynamic pricing whose advantages are analyzed in the study. This study focuses on qualitative analysis of the fair pricing that a company should implement keeping in mind the legality in the picture as well as its goodwill for customers and brand position in mind. The status quo damage and the potential loss a company will have to directly and indirectly bear have been mentioned keeping in mind the changing economical parameters due to the crisis. Many sectors have been affected and are struggling to resume regular basis operations. The study focused on all these issues.

\section{CONCLUSIONS}

The study discussed about the various changes brought about by the pandemic for businesses. The study focused mainly on the pricing strategies which companies should adopt during these times of crisis.

\subsection{Limitations}

The study conducted a qualitative and conceptual analysis of the pricing strategies adopted by companies. Primary data was not collected, and empirical analysis was not done. Collection of primary data and empirical analysis would have generated actionable results.

\subsection{Avenues of Future Research}

Research may collect primary data, conduct analysis on real-time data. They might conduct predictive analysis and suggest future course of actions for companies and businesses. The modern commerce post COVID crisis is yet to be analysed with palpable factors and parameters governing the business models of companies. This gives the study a further purview and direction to companies about how the various pivotal sectors can monitor and revamp their revenues above their bottom line and offsets. In future, researchers may conduct further qualitative analysis on the implications and de facto ground reality implementation of these pricing strategies concerning company's revenue model. From a customer's perspective, further analysis will involve knowing the value and persona of customers of these various sectors mentioned in the study. The pricing strategies adopted by companies will ensure proper customer-producer relationship. Such relationships will result in sustainable outcomes for businesses in the coming years. 


\section{REFERENCES}

Adegboyega, O. I. (2020). Influence of business environment on small and medium scale enterperises in Osun State. South Asian Journal of Marketing \& Management Research, 10(5), 84-98. doi:10.5958/2249877X.2020.00034.X

Adler, R. M. (2020). Competitive Marketing Strategy. In Bending the Law of Unintended Consequences (pp. 153-171). Springer. doi:10.1007/978-3-030-32714-9_10

Akbar, Y. H., \& Kisilowski, M. (2020). To bargain or not to bargain: Airlines, legitimacy and nonmarket strategy in a COVID-19 world. Journal of Air Transport Management, 88, 101867. doi:10.1016/j.jairtraman.2020.101867 PMID:32834693

Alstadsæter, A., Bjørkheim, J. B., Kopczuk, W., \& Økland, A. (2020). Norwegian and US policies alleviate business vulnerability due to the Covid-19 shock equally well (No. w27637). National Bureau of Economic Research.

Altunbas, Y., Manganelli, S., \& Marques-Ibanez, D. (2017). Realized bank risk during the great recession. Journal of Financial Intermediation, 32, 29-44. doi:10.1016/j.jfi.2017.08.001

Amankwah-Amoah, J. (2020). Stepping up and stepping out of COVID-19: New challenges for environmental sustainability policies in the global airline industry. Journal of Cleaner Production, 271, 123000. doi:10.1016/j. jclepro.2020.123000 PMID:32834564

Baker, S. R., Baugh, B., \& Sammon, M. C. (2020). Measuring Customer Churn and Interconnectedness (No. w27707). National Bureau of Economic Research.

Balduzzi, P., Brancati, E., Brianti, M., \& Schiantarelli, F. (2020). The Economic Effects of COVID-19 and Credit Constraints: Evidence from Italian Firms' Expectations and Plans (No. 1013). Boston College Department of Economics.

Barriga, M. E. G. B. D. S. (2019). Artificial intelligence applied to marketing management: trends and projections according to specialists (Doctoral dissertation).

Bhatti, A., Akram, H., Basit, H. M., Khan, A. U., Raza, S. M., \& Naqvi, M. B. (2020). E-commerce trends during COVID-19 Pandemic. International Journal of Future Generation Communication and Networking, 13(2), 1449-1452.

Blinder, A., Ehrmann, M., De Haan, J., \& Jansen, D. J. (2017). Necessity as the mother of invention: Monetary policy after the crisis. Economic Policy, 32(92), 707-755. doi:10.1093/epolic/eix013

Brotspies, H., \& Sellani, R. J. (2010). Wal-Mart: Getting Back to Growth Old Guard vs. Change Agent Conflict and the Impact on Growth. Journal of the International Academy for Case Studies, 16(3), 35.

Bryce, C., Ring, P., Ashby, S., \& Wardman, J. K. (2020). Resilience in the face of uncertainty: Early lessons from the COVID-19 pandemic. Journal of Risk Research, 1-8.

Budd, L., \& Ison, S. (2020). Responsible Transport: A post-COVID agenda for transport policy and practice. Transportation Research Interdisciplinary Perspectives, 6, 100151. doi:10.1016/j.trip.2020.100151 PMID:34173454

By, P., \& Jeetendra, K. (2020). Aerogen-bringing a lower risk of transmission of patient generated infectious aerosol for healthcare professionals in acute care settings compared to traditional nebulisers. Laboratory News.

Chakraborty, P. (2020). Indian Pharmaceuticals Industry in Global Scenario: An Appraisal. Journal of Health Management, 22(3), 0972063420937939. doi:10.1177/0972063420937939

Chen, K., Zha, Y., Alwan, L. C., \& Zhang, L. (2020). Dynamic pricing in the presence of reference price effect and consumer strategic behaviour. International Journal of Production Research, 58(2), 546-561. doi:10.108 $0 / 00207543.2019 .1598592$

Chen, P., Zhao, R., Yan, Y., \& Li, X. (2020). Promotional pricing and online business model choice in the presence of retail competition. Omega, 94, 102085. doi:10.1016/j.omega.2019.07.001 
Cohan, P. S. (2017). Growth via New or Current Customers. In Disciplined Growth Strategies (pp. 23-55). Apress. doi:10.1007/978-1-4842-2448-9_2

Curdia, V. (2020). Mitigating COVID-19 effects with conventional monetary policy. FRBSF Economic Letter, 2020(09), 1-05.

Cushing-Daniels, B. (2020). Rethinking Profit-Maximization in Second-Degree Price Discriminating Markets. Atlantic Economic Journal, 48(2), 223-235. doi:10.1007/s11293-020-09670-6

d'Aguiar, R. F., da Silva, J. M., da Silva, A. M. J. F., Marques, M., \& de Gaspi, R. H. (2020). Consequences from the pandemic. Revista do Fórum Internacional de Ideias, 11(1), 12-12.

Dong, J., Rao, B., Liu, Y., Jiang, L., Lu, W., \& Guo, Q. (2019). Pricing Strategies for Different Periods During Subsequent Selling Season for Seasonal Products. IEEE Access: Practical Innovations, Open Solutions, 8, 39479-39490. doi:10.1109/ACCESS.2019.2953284

Ferguson, J. L. (2014). Implementing price increases in turbulent economies: Pricing approaches for reducing perceptions of price unfairness. Journal of Business Research, 67(1), 2732-2737. doi:10.1016/j. jbusres.2013.03.023

Gao, F. (2020). Cause Marketing: Product Pricing, Design, and Distribution. Manufacturing \& Service Operations Management, 22(4), 775-791. doi:10.1287/msom.2019.0772

Gu, S., Kelly, B., \& Xiu, D. (2020). Empirical asset pricing via machine learning. Review of Financial Studies, 33(5), 2223-2273. doi:10.1093/rfs/hhaa009

Haleem, A., Javaid, M., \& Vaishya, R. (2020). Effects of COVID 19 pandemic in daily life. Current Medicine Research and Practice. doi:10.1016/j.cmrp.2020.03.011

Hammond, R., \& Czaban, L. (2018). Post-deregulation passenger selection of US airports (Doctoral dissertation). University of Manchester.

Hao, F., Xiao, Q., \& Chon, K. (2020). COVID-19 and China's Hotel Industry: Impacts, a Disaster Management Framework, and Post-Pandemic Agenda. International Journal of Hospitality Management, 90, 102636. doi:10.1016/j.ijhm.2020.102636 PMID:32834356

Hartmann, N., \& Lussier, B. (2020). Managing the sales force through the unexpected exogenous COVID-19 crisis. Industrial Marketing Management, 88, 101-111. doi:10.1016/j.indmarman.2020.05.005

Helmold, M. (2020). Pricing Elements and Price Elasticity. In Total Revenue Management (TRM) (pp. 13-27). Springer. doi:10.1007/978-3-030-46985-6_2

Hinterhuber, A. (2017). Implementing pricing strategies. Journal of Revenue and Pricing Management, 17(1), 1-2. doi:10.1057/s41272-017-0129-6

Iacus, S. M., Natale, F., Santamaria, C., Spyratos, S., \& Vespe, M. (2020). Estimating and projecting air passenger traffic during the COVID-19 coronavirus outbreak and its socio-economic impact. Safety Science, 129, 104791. doi:10.1016/j.ssci.2020.104791 PMID:32377034

Jabarzare, N., \& Rasti-Barzoki, M. (2020). A game theoretic approach for pricing and determining quality level through coordination contracts in a dual-channel supply chain including manufacturer and packaging company. International Journal of Production Economics, 221, 107480. doi:10.1016/j.ijpe.2019.09.001

Jommi, C., Armeni, P., Costa, F., Bertolani, A., \& Otto, M. (2020). Implementation of value-based pricing for medicines. Clinical Therapeutics, 42(1), 15-24. doi:10.1016/j.clinthera.2019.11.006 PMID:31882225

Kandpal, M., \& Patel, K. A. (2020). Evaluation of the Dynamic Pricing Model in Cloud. International Journal of Security and Privacy in Pervasive Computing, 12(3), 20-29. doi:10.4018/IJSPPC.2020070102

Kapoor, P. (2020). COVID-19 and its Likely Impact on the Indian Economy vis-a-vis Inflation, Inflation Expectations and Future Scenario. Journal of Economics \& Policy Analysis, 1(1), 95-104.

Karabag, S. F. (2020). An unprecedented global crisis! the global, regional, national, political, economic and commercial impact of the coronavirus pandemic. Journal of Applied Economics and Business Research, 10(1), $1-6$. 
Kerr, B. P. (2020). Clear skies or turbulence ahead? The international civil aviation organization's obligation to mitigate climate change. Utrecht Law Review, 16(1), 101-116. doi:10.36633/ulr.551

Kim, M., Roehl, W., \& Lee, S. K. (2019). Effect of hotels' price discounts on performance recovery after a crisis. International Journal of Hospitality Management, 83, 74-82. doi:10.1016/j.ijhm.2019.04.006

Krutova, A., Nesterenko, O., \& Levina, M. (2019). Transfer pricing as a means of the state tax base optimization. Fundamental and Applied Researches in Practice of Leading Scientific Schools, 31(1), 100-107.

Kunzmann, K. R. (2020). Smart Cities After Covid-19: Ten Narratives. disP-The Planning Review, 56(2), $20-31$.

Kusnadi, A. D., \& Einarsson, F. (2020). Marketing Strategy for Software as a Service Companies within the Logistics Vertical Software Niche: A multiple case study. Academic Press.

Landier, A., \& Thesmar, D. (2020). Earnings expectations in the covid crisis (No. w27160). National Bureau of Economic Research.

Lessard, D. (2019). Risk Management for Companies Operating in Emerging Markets. In The Oxford Handbook of Management in Emerging Markets (p. 427). Oxford University Press.

Lew, A. A., Cheer, J. M., Haywood, M., Brouder, P., \& Salazar, N. B. (2020). Visions of travel and tourism after the global COVID-19 transformation of 2020. Tourism Geographies, 22(3), 1-12. doi:10.1080/1461668 8.2020 .1770326

Li, J., Hallsworth, A. G., \& Coca-Stefaniak, J. A. (2020). Changing Grocery Shopping Behaviours Among Chinese Consumers At The Outset Of The COVID-19 Outbreak. Tijdschrift voor Economische en Sociale Geografie, 111(3), 574-583. doi:10.1111/tesg.12420 PMID:32836486

Li, T. (2020). A SWOT analysis of China's air cargo sector in the context of COVID-19 pandemic. Journal of Air Transport Management, 88, 101875. doi:10.1016/j.jairtraman.2020.101875 PMID:32834695

Li-Ying, J., \& Nell, P. (2020). Navigating opportunities for innovation and entrepreneurship under COVID-19. California Management Review.

Liozu, S. M. (2019). Make pricing power a strategic priority for your business. Business Horizons, 62(1), 117-128. doi:10.1016/j.bushor.2018.09.006

Liu, X., \& Wang, W. (2020). Export Risk Prevention of Hunan Breeding Industry Based on Green Drive. Journal of Coastal Research, 103(SI), 37-41.

Lu, X., Zhang, H., \& Zhang, D. (2020). Research on real-time pricing strategy for load serving entity based on simultaneous perturbation stochastic approximation. $E \& E S, 467(1), 012202$.

Ma, Z. (2020). Dynamic Price-Based Coordination Methods. In Decentralized Charging Coordination of Largescale Plug-in Electric Vehicles in Power Systems (pp. 163-180). Springer. doi:10.1007/978-981-13-7652-8_6

Marolt, M., Zimmermann, H. D., \& Pucihar, A. (2020). Enhancing Marketing Performance Through EnterpriseInitiated Customer Engagement. Sustainability, 12(9), 3931. doi:10.3390/su12093931

Marth, D., Ploder, C., \& Dilger, T. (2020). The Upcoming Role of the Enterprise Architect—From Overseeing Visualization and Documentation to Becoming the Enabler for Change and Innovation. In Economic and Financial Challenges for Balkan and Eastern European Countries (pp. 255-272). Springer. doi:10.1007/9783-030-39927-6_16

McAleer, M. (2020). Prevention Is Better Than the Cure: Risk Management of COVID-19. Journal of Risk and Financial Management, 13(3), 1-5. doi:10.3390/jrfm13030046

Mehboob, D. (2020). Coronavirus disrupts corporate reporting and compliance. International Tax Review.

Mohamad, A. H., Hamzah, A. A., Ramli, R., \& Fathullah, M. (2020, May). E-Commerce Beyond the Pandemic Coronavirus: Click and Collect Food Ordering. IOP Conference Series. Materials Science and Engineering, 864(1), 012049. doi:10.1088/1757-899X/864/1/012049

Nair, G. K. (2019). Dynamics of pricing and non-pricing strategies, revenue management performance and competitive advantage in hotel industry. International Journal of Hospitality Management, 82, $287-297$. doi:10.1016/j.ijhm.2018.10.007 
Naumzik, C., \& Feuerriegel, S. (2020, April). One Picture Is Worth a Thousand Words? The Pricing Power of Images in e-Commerce. In Proceedings of The Web Conference 2020 (pp. 3119-3125). doi:10.1145/3366423.3380086

Nik Hashim, N. M. H., Hock Ann, Y., Ansary, A., \& Xavier, J. A. (2020). Contingent Effects of Decision-making and Customer Centricity on Public-Sector Innovation Success. Journal of Nonprofit \& Public Sector Marketing, 1-35. doi:10.1080/10495142.2020.1761000

Nunes, C. R., \& Machado, M. J. C. V. (2020). Benchmarking in the hotel industry: The use of USALI. International Journal of Process Management and Benchmarking, 10(3), 382-396. doi:10.1504/IJPMB.2020.107939

Park, H. (2020). Enhancing for Consumer Engagement in Sustainable Choice: A Series of Essays with a Theoretical Perspective (Doctoral dissertation). University of Wyoming.

Pich, K., \& Sardjono, W. (2020). The Performance of Information System in Facilitating Work Communication by Online-Based Application During Covid-19 Pandemic Crisis. Airlangga Journal of Innovation Management, l(1), 21-31. doi:10.20473/ajim.v1i1.19398

Purwanto, P. W. T. (2018). CEK PLAGIASI_The Role of Dynamic Pricing and Dynamic Bundling on Unfairness Pricing Perceptions. International Journal of Management Excellence, 12(1), 1783-1790. doi:10.17722/ijme. v12i1.1053

Raja, J. Z., Frandsen, T., Kowalkowski, C., \& Jarmatz, M. (2020). Learning to discover value: Value-based pricing and selling capabilities for services and solutions. Journal of Business Research, 114, 142-159. doi:10.1016/j. jbusres.2020.03.026

Ranjan, J. (2016). Big data applications in healthcare. In Big Data: Concepts, Methodologies, Tools, and Applications (pp. 1247-1259). IGI Global. doi:10.4018/978-1-4666-9840-6.ch056

Rascão, J. P. (2019). Management in the Context of Turbulence and Complexity. International Journal of Strategic Decision Sciences, 10(4), 1-17. doi:10.4018/IJSDS.2019100101

Schoonveld, E. (2020). The price of global health: drug pricing strategies to balance patient access and the funding of innovation. Routledge. doi:10.4324/9780429320712

Scott, I. A. (2020). COVID-19 pandemic and the tension between the need to act and the need to know. Internal Medicine Journal, 50(8), 904-909. doi:10.1111/imj.14929 PMID:32881234

Seaman, B. A. (2018). Static and dynamic pricing strategies: how unique for nonprofits? In Handbook of Research on Nonprofit Economics and Management. Edward Elgar Publishing. doi:10.4337/9781785363528.00018

Shah, S. (2020). Economy impact of covid-19-A case study of India (Doctoral dissertation).

Sibbald, B. (2017). Fair pricing or pricing for profit? Canadian Medical Association Journal, 189(20), E733E734. doi:10.1503/cmaj.1095429 PMID:28536135

Sigala, M. (2020). Tourism and COVID-19: impacts and implications for advancing and resetting industry and research. Journal of Business Research.

Smagulova, S. A., Doskeyeva, G. Z., \& Radko, N. (2016). Analysis of the oil market and the role of investment in the Agrarian sector in Kazakhstan. International Journal of Economics and Financial Issues, 6(2), 798-806.

Spychalska-Wojtkiewicz, M. (2020). The Relation between Sustainable Development Trends and Customer Value Management. Sustainability, 12(14), 5496. doi:10.3390/su12145496

Sravani, S., Tejaswini, T., \& Gowthami, C. (2016). Evolutionary Challenges of a Start up: ShopitSoon. FIIB Business Review, 5(5), 9-15. doi:10.1177/2455265820160102S

Suau-Sanchez, P., Voltes-Dorta, A., \& Cugueró-Escofet, N. (2020). An early assessment of the impact of COVID-19 on air transport: Just another crisis or the end of aviation as we know it? Journal of Transport Geography, 86, 102749. doi:10.1016/j.jtrangeo.2020.102749 PMID:32834670

Taleizadeh, A. A., \& Sadeghi, R. (2019). Pricing strategies in the competitive reverse supply chains with traditional and e-channels: A game theoretic approach. International Journal of Production Economics, 215, 48-60. doi:10.1016/j.ijpe.2018.06.011 
Tamraz, M., \& Yang, Y. (2017). Price Optimisation for New Business. SSRN Electronic Journal. 10.2139/ ssrn. 3074317

Teng, Y. M., Wu, K. S., \& Chou, C. Y. (2020). Price or Convenience: What Is More Important for Online and Offline Bookings? A Study of a Five-Star Resort Hotel in Taiwan. Sustainability, 12(10), 3972. doi:10.3390/ su12103972

Uncles, M. D., Dowling, G. R., \& Hammond, K. (2003). Customer loyalty and Customer Loyalty Programs. Journal of Consumer Marketing, 20(4), 294-316. doi:10.1108/07363760310483676

Valente, C., Valente, C., \& Vincenti, F. (2020). Adapting transfer pricing policies to cope with COVID-19. International Tax Review.

Valkov, T. (2006). From theory to practice: Real-world applications of scientific pricing across different industries. Journal of Revenue and Pricing Management, 5(2), 143-151. doi:10.1057/palgrave.rpm.5160037

Vassiliadis, C. A., Skoulas, I. G., \& Gkarane, S. K. (2020). Small-Scale Sports Event Sponsorship. In Principles and Practices of Small-Scale Sport Event Management (pp. 192-216). IGI Global. doi:10.4018/978-1-79984757-1.ch010

Vinod, B. (2020). The COVID-19 pandemic and airline cash flow. Journal of Revenue and Pricing Management, 19(4), 228-229. doi:10.1057/s41272-020-00251-5

Wang, H., \& Huang, H. (2019, December). Excess Goodwill and Corporate Performance-Based on the Adjustment Effect of Corporate Market Power. In 2019 International Conference on Economic Management and Model Engineering (ICEMME) (pp. 524-529). IEEE. doi:10.1109/ICEMME49371.2019.00110

Wang, L., Song, H., Yang, H., \& Huang, F. (2020). Optimal dynamic pricing for non-instantaneous deteriorating items dependent on price and time demand. International Journal of Computing Science and Mathematics, 11(4), 372-384. doi:10.1504/IJCSM.2020.107597

Wossink, J. A. A. (2020). Patriarchy, Pandemics and the Gendered Resource Curse Thesis: Evidence from Petroleum Geology. Academic Press.

Yan, N., Liu, Y., Xu, X., \& He, X. (2020). Strategic dual-channel pricing games with e-retailer finance. European Journal of Operational Research, 283(1), 138-151. doi:10.1016/j.ejor.2019.10.046

Yang, J. Y. (2020). The Moral of Pricing. In The Pricing Puzzle (pp. 147-150). Springer. doi:10.1007/978-3030-50777-0_23

Yeoman, I. (2013). The importance of consumer behaviour. Journal of Revenue and Pricing Management, 12(5), 383-384. doi:10.1057/rpm.2013.24

Y1lmaz, Y., Ünal, C., \& Dursun, A. (2019). The effects of distribution channels on the selling prices of hotels in time of crisis. International Journal of Economics and Management Engineering, 13(6), 929-932.

Zhang, Y. (2020). Corporate R\&D Investments Following Competitors' Disclosures: Evidence from the Drug Development Process (Doctoral dissertation). University of Pittsburgh. 
Lovely Chopra is a final year engineering student from Netaji Subhas University of Technology, New Delhi, India. $\mathrm{He}$ is currently majoring in Instrumentation and Control Engineering. He has a deep interest in marketing and mathematics. He has done internships at Kotak Mahindra Bank, India and Kite, India to explore different avenues. $\mathrm{He}$ is also an avid follower of the game of football.

Rohan Shareshtha Verma is pursuing Bachelor of Technology (B. Tech.) in Mechanical Engineering from Netaji Subhas Institute of Technology, one of the most reputed technical institutes of India, under University of Delhi. $\mathrm{He}$ is actively looking for new avenues in the field of marketing management because of his strong interest and passion towards marketing. He has done his summer internship at Bharat Heavy Electricals Limited, India as an engineer Intern working under relevant departments for future projects. He possesses a detailed understanding of engineering and layout of heat exchangers and water coolers. He is also actively associated with NGOs and social work.

Pratap Chandra Mandal is an Assistant Professor (Marketing) at Indian Institute of Management, Shillong, India. He has completed graduate degree from the reputed Indian Institute of Technology, Kharagpur (IIT Kharagpur), India (Bachelor of Technology in Mechanical Engineering), post-graduate degree from Vinod Gupta School of Management, IIT Kharagpur (Masters in Business Administration), PhD (Marketing) from Vinod Gupta School of Management, IIT Kharagpur. His research concerns customer relationship management, customer satisfaction, services marketing, marketing intelligence, and qualitative methods in management. He is the editor-in-chief of two international journals and is on the editorial board of journals like Journal of Global Marketing. Pratap has won several prestigious scholarships and awards throughout his academic career. 